\title{
The relationship of temporomandibular disorders with headaches: a retrospective analysis
}

\author{
Temporomandibular bozuklukların başağrılarn ile ilişkisi: \\ Retrospektif bir inceleme
}

Nilüfer ÇAKIR ÖZKAN,' Fatih ÖZKAN²

\begin{abstract}
10
Summary

Objectives: The objective of this study was to retrospectively analyze the incidence of the concurrent existence of temporomandibular disorders (TMD) and headaches.

Methods: Forty patients ( 36 female, 4 male, mean age: $29.9 \pm 9.6$ years) clinically diagnosed with TMD were screened. Patient records were analyzed regarding: range of mouth opening, temporomandibular joint (TMJ) noises, pain on palpation of the TMJ and masticatory muscles and neck and upper back muscles, and magnetic resonance imaging of the TMJ.

Results: According to patient records, a total of 40 (66.6\%) patients were diagnosed with TMD among 60 patients with headache. Thirty-two (53\%) patients had TMJ internal derangement (ID), 8 (13\%) patients had only myofascial pain dysfunction (MPD) and 25 (41.6\%) patients had concurrent TMJ ID/MPD. There were statistically significant relationships between the number of tender masseter muscles and MPD patients $(p=0.04)$ and between the number of tender medial pterygoid muscles and patients with reducing disc displacement (RDD) ( $\mathrm{p}=0.03)$.

Conclusion: The TMJ and associated orofacial structures should be considered as possible triggering or perpetuating factors for headaches, especially tension-type. There might be a significant connection between TMD and headache. However, most medical and dental practitioners are unaware of this relationship. Therefore, a careful evaluation of the TMJ and associated orofacial structures is required for a correct interpretation of the craniofacial pain in headache patients, and these patients should be managed with a multidisciplinary approach.
\end{abstract}

Key words: Headache; temporomandibular disorders.

\section{Özet}

Amaç: Bu çalı̧̧mada, başağrısı ve temporomandibular bozuklukların (TMB) birlikte görülme sıklı̆̆ı retrospektif olarak incelendi.

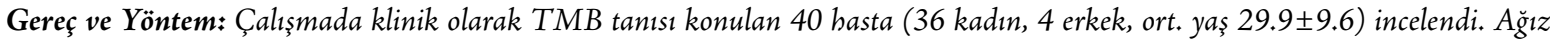
açılığı oranı, temporomandibular eklem (TME) sesleri, TME, çiğneme kasları, boyun ve sırt kaslarının palpasyona hassasiyeti ve TME'nin manyetik rezonans incelemesini içeren hasta kayitları analiz edildi.

Bulgular: Hastaların kayıtlarına göre, başağrısı şikayeti bulunan 60 basta içinde TMB tanısı konulan toplam 40 (\%66.6) basta vard. Hastalarm 32'sinde (\%53) TME internal düzensizliği (ID), 8'inde (\%13) miyofasiyal disfonkiyon (MFD) ve 25'inde (\%41.6) birlikte MFD/TME İD vard. Hassas masseter kasların sayısı ile MPD hastaları $(p=0.04)$ ve hassas medial pterygoid kasların sayısı ile redüksiyonlu disk deplasmanı bulunan hastalar $(p=0.03)$ arasında istatistiksel olarak anlamlı ilişki bulundu.

Sonuç: Sonuç olarak, TME ve ilişkili orofasiyal yapılar başağrıları için mubtemel tetikleyici veya kronikleştirici faktörlerdir. Temporomandibular bozukluk ve başağrısı arasında önemli bir ilişki olabilir. Bununla birlikte, çoğu tıp ve diş bekimleri bu ilişkinin farkında olmayabilir. Bu nedenle, başağrısı bulunan hastalarda baş-yüz ağrısının doğru bir şekilde değerlendirilmesi için TME ve ilişkili orofasiyal yapiların dikkatli incelenmesi gereklidir, bu hastalar multidisipliner yaklaşımla tedavi edilmelidir.

Anahtar sözcükler: Başağrısl; temporomandibular bozukluklar.

Department of 'Oral and Maxillofacial Surgery, ${ }^{2}$ Anesthesiology, Gaziosmanpaşa University Faculty of Medicine, Tokat, Turkey Gaziosmanpaşa Üniversitesi Tıp Fakültesi, 'Ağız Diş Çene Hastalıkları ve Cerrahisi Kliniği, 'Anesteziyoloji ve Reanimasyon Anabilim Dalı, Tokat Submitted - April 30, 2010 (Başvuru tarihi - 30 Nisan 2010) Accepted after revision - July 23, 2010 (Düzeltme sonrası kabul tarihi - 23 Temmuz 2010) 


\section{Introduction}

Headaches are a common affliction in the general population. The most frequent form appears to be muscle tension-type headaches. Interestingly, one of the three most commonly reported symptoms by patients with temporomandibular disorders (TMD) is muscle tension-type headaches. In the literature, TMD have been cited as a possible causes for headaches and there was a positive relationship between TMD and the prevalence of headaches. In addition, the treatment of symptomatic TMD has resulted in significant decrease in headache complaints. ${ }^{[1,2]}$

TMD is the general term used to describe the manifestation of pain and/or dysfunction of the temporomandibular joint (TMJ) and associated structures. TMDs are common in the general population and include intra-articular and extra-articular disorders. ${ }^{[3-5]}$

The most common intra-articular disorders involving the TMJ are TMJ internal derangement (TMJ ID) and TMJ osteoarthritis (TMJ OA). Disc displacement (DD) has been defined as an abnormal relationship of the articular disc relative to the condylar head, fossa and the articular eminence at the closed-mouth position; normal disc-condyle relationship might reestablish in maximal opening reducing disc displacement (RDD) or not non-reducing disc displacement (NRDD). The final stage of the TMJ ID progression is the possible development of TMJ OA. ${ }^{[6,7]}$

Myofascial pain dysfunction (MPD) is the most common extra-articular temporomandibular disorder. There are many synonyms for this condition including TMJ dysfunction syndrome, craniomandibular dysfunction, myofascial pain dysfunction syndrome (MPDS). ${ }^{[5]}$ Masticatory MPD is characterized by tender trigger points in these muscles. In the head and neck region, MPD can manifest as tension headache, tinnitus, TMJ pain and torticollis. A trigger point $(\operatorname{Tr} \mathrm{P})$ is a focus of hyperirritability in a tissue that, when compressed is locally tender and hypersensitive and gives rise referred pain a tenderness. ${ }^{[8,9]}$ Although the pain occurs most often in the region over the $\mathrm{TrP}$, pain can be referred to areas distant from the TrPs.

It has been known that there was overlap between the headaches and TMD for signs and symptoms.
Therefore, it is important that the clinicians can identify the concurrent existence of TMD in headache patients and triage the patient to a clinician knowledgeable in the diagnosis and treatment of TMD for further evaluation. The objective of the present study was to retrospectively analyse the relationship of the TMJ disorders and headache.

\section{Materials and Methods}

The sample consisted of 40 subjects, (aged 29.9 \pm 9.6 years, 36 female and 4 male) seeking therapy for headache in Pain Clinic of Faculty of Medicine, University of Gaziosmanpaşa between 2006 and 2008. The patients were selected from 60 headache patients. All patients were examined by pain specialist and dentist. In our clinic, the diagnosis of TMD has been made if the patient exhibits more than one of the following signs and/or symptoms in any combination. ${ }^{[10]}$

- Pain on palpation of the TMJ

- Pain on palpation of associated mandibular muscles

- Limitation and/or deviation of mandibular movement

- Joint sounds and headache

The following factors have been recorded on routine clinical examination, range of motion of the jaw, noting TMJ noises, pain to palpation of the TMJ and masticatory muscles as well as neck and upper back muscles. TMJ ID has been bilaterally evaluated according to magnetic resonance imaging (MRI). Tenderness of the muscles of mastication and the neck muscles have been bilaterally assessed by means of digital palpation and functional manipulation. The tenderness in the muscle has been recorded as being present or absent.

The chi-squared test was used for comparison of the distribution of variables in different TMD groups (MPD, RDD and NRDD). Kappa measure of agreement test was used to determine the agreement of the clinical symptoms and the diagnosis. $\mathrm{P}$ value $<0.05$ was considered statistically significant. Analyses were performed using commercial software (PASW v.18, SPSS, Chicago, IL). 
Table 1. The distribution of the patients with temporomandibular disorders in headache patients

\begin{tabular}{lcc}
\hline & Patients & \% \\
\hline Headache & 60 & 100 \\
Temporomandibular disorders & 40 & 66.6 \\
Myofascial pain dysfunction & 8 & 13 \\
TMJ ID/MPD & 25 & 41.6 \\
TMJ ID & 32 & 53 \\
\hline
\end{tabular}

TMJ ID: Temporomandibular joint internal derangement; MPD: Myofascial pain dysfunction.

\section{Results}

According to patients records, there were totally 40 (66.6\%) patients diagnosed with TMD in 60 headache patients. Thirty-two (53\%) patients had TMJ ID, $8(13 \%)$ patients had only MPD and 25 (41.6\%) patients had concurrent TMJ ID/MPD (Table 1).

In our series, 8 (20\%) TMD patients had received previous treatment and $13(32.5 \%)$ TMD patients had previous doctors for treatment of crainofacial pain. Twenty-eight (70\%) of the TMD patients had a pain at rest, $36(90 \%)$ of the patients had pain during mandibular movements. Mean maximal mouth opening was $34.4 \pm 6.9 \mathrm{~mm}$.

It was found that totally 44 (55\%) joints had disc displacement 29 (36\%) were reducing, 15 (18.75\%) non-reducing) and the remaining $36(45 \%)$ were normal disc position according to MRI examination of the TMJ. It was found that the TMJs had 32 (40\%) clicking, $12(15 \%)$ crepitus (Table 2).
Table 2. The distribution of the different variables which were obtained from TMD patients records

\begin{tabular}{lcc}
\hline & Patients & $\%$ \\
\hline Clicking & 32 & 40 \\
Crepitus & 12 & 15 \\
Disc displacement & 44 & 55 \\
Reducing disc displacement & 29 & 36 \\
Non-reducing disc displacement & 15 & 18.7 \\
Without disc displacement & 36 & 45 \\
TrP Masseter muscle & 59 & 73.75 \\
Trp medial pterygoid muscle & 56 & 70 \\
TrP lateral pterygoid muscle & 65 & 81.25 \\
TrP temporalis muscle & 39 & 48.75 \\
TrP sterno-cleido mastoideus muscle & 52 & 52.50 \\
TrP splenius capitus muscle & 27 & 58.75 \\
TrP trapezius muscle & 64 & 80 \\
\hline
\end{tabular}

TrP: Trigger points.

The number of the tender muscles were shown in Table 2. The distribution of the tender muscles in MPD and TMJ ID (reducing and non-reducing) was shown in Table 3.

There were statistically significant relationship between the number of tender masseter muscles (MM) and MPD patients ( $\mathrm{p}=0.04)$ and between the number of tender medial pterygoid muscles (MPM) and patients with RDD. It was found that the number of the tender lateral pterygoid muscles (LPM) was the highest in patients with NRDD without statistical significance (Table 3).

Table 3. The number of the tender muscles in temporomandibular disorders

\begin{tabular}{lcccc}
\hline Tender muscles & MPD & RDD & NRDD & p \\
\hline MM\% & 58.3 & 48.3 & 26.7 & 0.04 \\
MPM\% & 44.4 & 48.3 & 80 & 0.03 \\
LPM\% & 58.3 & 44.8 & 86.7 & 0.1 \\
TM\% & 77.8 & 82.8 & 80 & 0.7 \\
SCMM\% & 50 & 44 & 60 & 0.8 \\
SCM\% & 60 & 40 & 46 & 0.1 \\
TRP\% & 80 & 75 & 70 & 0.7 \\
\hline
\end{tabular}

MPD: Myofascial pain dysfunction; RDD: Reducing disc displacement; NRDD: Non-reducing disc displacement; TrPs: Trigger points; MM: Masseter muscle; MPM: Medial pterygoid muscle; LPM: Lateral pterygoid muscle; TM: Temporalis muscle; SCMM: Sterno-cleido mastoideus muscle; SCM: Splenius capitus muscle; TRM: Trapezius muscle. 


\section{Discussion}

TMDs are principally musculoskeletal, orthopedic and neurologic in nature. There are many comorbid conditions to TMD pain that reflect common etiologic factors and mechanisms of pain. These disorders include joint disk displacement and osteoarthritis, malocclusion, connective tissue diseases, neuropathic pain disorders, migraine and tensiontype headaches. ${ }^{[11,12]}$ Patients with TMD frequently suffer from headache. Failure to address the entire problem, including concomitant diagnoses, and contributing factors, may lead to failure to resolve the pain. Major characteristic of some of these patients is the failure of traditional approaches to resolve the problem. Each clinician who is confronted with a patient who has headache needs to recognize and address the whole problem to maximize the potential for a successful outcome. ${ }^{[13,14]}$

Clinical studies reveal that many patients suffering from headaches have seen many clinicians, or received numerous medications and multiple treatments for years. According to Francis, patients with headache do not realize that tension-type headaches may be caused by TMD and they typically do not seek treatment from dental practitioners. Moreover these patients discuss their headache symptoms with their dentists. ${ }^{[15]}$ In one study of 102 consecutive patients who had craniofacial pain $59.8 \%$ had muscle pain), the mean duration of pain was 6.0 years, with $28.8 \%$ previous treatment sessions, $5.1 \%$ previous doctors, and $6.4 \%$ previous medications. Our patients had a history of $20 \%$ previous treatment and $32.5 \%$ previous doctors. ${ }^{[16]}$

There is a significant evidence for the existence of a relationship between TMD and headaches. The most prominent etiological theory proposed for TMD involvement in headache pain is that it can occur as a result of a dysfunctional masticatory system. Lynn described the presence of interactions among structures of the craniomandibular complex, and stated that, when the muscle groups are unbalanced, physiological changes occur that lead to symptoms of tension-type headaches. ${ }^{[17]}$ Rauhala et al. concluded that 25 patients suffering from facial pain combined with TMD was most probably of myogenic origin. ${ }^{[18]}$ Trejo and Michael found that $73 \%$ TMD patients reported headache and 60\% headache patients reported TMD symptoms. In accordance with the literature, we found that 40 $(66.6 \%)$ of the headache patients had TMD and 25 (41.6\%) patients had concurrent TMJ ID/MPD. ${ }^{[15]}$

There were no patients in our series who presented with clicking or joint noise alone without tenderness around the TMJ and the associated masticatory and neck muscles. Ekberg et al. found that their patients had $71.6 \%$ pain at rest, $98 \%$ pain during mandibular movements and $43 \%$ reciprocal clicking in their case series with myofascial pain. ${ }^{[19]}$ We found $70 \%$ pain at rest, $90 \%$ pain during mandibular movements and $40 \%$ reciprocal clicking in our case series with TMD. The presence of a reciprocal click suggests the presence of TMJ ID with reduction. In regards to, TMJ ID without reduction and TMJ OA, no reciprocal click is usually present, however, pain to palpation of the TMJ and pain on passive streching of the jaw are common findings. ${ }^{[5]}$ Limited mouth opening (mean $=34.4 \pm 6.9)$ resulted from painful jaw movements in our series.

It has been hypothesized that any stage of TMJ ID can cause secondary muscle disorders due to the altered disc/condyle relationship. This may result in, tension-type headache with pericranial tenderness because of the involvement of the temporalis muscle(s). The number of the painful temporalis muscle was $39(48.75 \%)$ in our series, also. ${ }^{[7]}$ It has also been shown that $42 \%$ of MPD patients have concurrent TMJ ID or TMJ OA (30.4\% and $11.6 \%$, in respectively). ${ }^{[20]}$ Nilner et al. found that $24.6 \%$ of MPD patients had TMJ disc displacement. ${ }^{[21]}$ We found $41.6 \%$ of the TMD patients had concurrent TMJ ID/MPD and $12.5 \%$ had TMJ OA. Results of the present study are accordance with the literature which suggest the existence of a certain degree of comorbidity between myofascial pain dysfunction syndrome and articular disc derangements. However, some of the clinical signs of the TMJ ID differ from MPD. Especially, the presence of reciprocal clicking of the TMJ or pain with maximum jaw opening are important signs to distinguish TMJ ID patients from MPD patients. The jaw movements may be painful and/or limited with active movements, but not with passive streching and imaging studies are normal in MPD patients. ${ }^{[7]}$ In this study, we found significant relationship between TMJ ID 
and the tenderness of the MPM and LPM. However, there was a significant relationship between tender MM and MPD. Therefore, our results indicate that tenderness of the MPM and LPM is more specific in identifying the TMJ ID.

Existence of a relation between headaches and TMD is clear. Especially tension-type headaches is widespread and is the most common symptom reported by TMD patients. The literatur support that the treatment of TMD can result in significant headache relief as well as relief of other TMD symptoms. ${ }^{[15]}$ Simple cases can be managed by a single clinician with palliative therapy. But complex patients should be managed most effectively within a interdisciplinary clinic setting that uses a team of clinicians including dentist, physical therapist, pain specialist, psycohologist to address different aspects of the problem in a concerted fashion. To improve outcomes, it is important to match the level of complexity of the management program and to distinguish between TMJ disorders and headaches. ${ }^{[22-25]}$ Due to the retrospective nature of our study, we did not access to treatment results of all patients.

As a consequense, the TMJ and associated orofacial structures should be considered as possible triggering or perpetuating factors for especially tensiontype headaches. There might be a significant connection between TMD and headache. However, most medical and dental practitioners are not aware of this relationship. Therefore, a careful evaluation of TMJ and associated orofacial structures is required for a correct interpretation of the etiology of pain in headache patients and these patients should be managed with multidisciplinary approach.

\section{References}

1. Jensen R. Pathophysiological mechanisms of tension-type headache: a review of epidemiological and experimental studies. Cephalalgia 1999;19(6):602-21.

2. Cooper BC, Kleinberg I. Examination of a large patient population for the presence of symptoms and signs of temporomandibular disorders. Cranio 2007;25(2):114-26.

3. Laskin DM. Diagnosis and etiology myofascial pain and dysfunction. Oral Maxillofac Surg Clin North Am 1995;7:73-78.

4. Friedman $\mathrm{MH}$, Weisberg J. Temporomandibular joint disorders: diagnosis and treatment. Chicago: Quintessence Publishing Company; 1985. p. 119-140.

5. Gray RJM, Davies SJ, Quayle AA. A clinical guide to temporomandibular disorders. London: BDJ Books; 1997. p. 1-43.

6. Al-Ani Z, Gray RJ, Davies SJ, Sloan P, Glenny AM. Stabili- zation splint therapy for the treatment of temporomandibular myofascial pain: a systematic review. J Dent Educ 2005;69(11):1242-50.

7. Schiffman E, Haley D, Baker C, Lindgren B. Diagnostic criteria for screening headache patients for temporomandibular disorders. Headache 1995:35(3):121-4.

8. Gray RJ, Davies SJ. Occlusal splints and temporomandibular disorders: why, when, how? Dent Update 2001;28(4):194-9.

9. Murphy GJ. Physical medicine modalities and trigger point injections in the management of temporomandibular disorders and assessing treatment outcome. Oral Surg Oral Med Oral Pathol Oral Radiol Endod 1997;83(1):118-22.

10. Dworkin SF, LeResche L. Research diagnostic criteria for temporomandibular disorders: review, criteria, examinations and specifications, critique. J Craniomandib Disord 1992;6(4):301-55.

11. Velly AM, Gornitsky M, Philippe P. Contributing factors to chronic myofascial pain: a case-control study. Pain 2003;104(3):491-9.

12. Glaros AG, Glass EG, Brockman D. Electromyographic data from TMD patients with myofascial pain and from matched control subjects: evidence for statistical, not clinical, significance. J Orofac Pain 1997;11(2):125-9.

13. Molina OF, dos Santos J Jr, Nelson SJ, Grossman E. Prevalence of modalities of headaches and bruxism among patients with craniomandibular disorder. Cranio 1997;15(4):314-25.

14. Fricton J. Myogenous temporomandibular disorders: diagnostic and management considerations. Dent Clin North Am 2007;51(1):61-83, vi.

15. Cooper BC, Kleinberg I. Relationship of temporomandibular disorders to muscle tension-type headaches and a neuromuscular orthosis approach to treatment. Cranio 2009;27(2):101-8.

16. Friction JR, Hathaway KM, Bromaghim C. Interdisciplinary management of patients with TMJ and craniofacial pain: characteristics and outcome. J Craniomandib Disord. 1987;1(2):115-22.

17. Lynn JM, Mazzocco MW: Neuromuscular differentiation of craniocervical pain: Is it headache or TMD? Am J Pain Mgmt 1993;3(4):181-90.

18. Rauhala K, Oikarinen KS, Raustia AM. Role of temporomandibular disorders (TMD) in facial pain: occlusion, muscle and TMJ pain. Cranio 1999;17(4):254-61.

19. Ekberg E, Vallon D, Nilner M. The efficacy of appliance therapy in patients with temporomandibular disorders of mainly myogenous origin. A randomized, controlled, short-term trial. J Orofac Pain 2003;17(2):133-9.

20. Fricton JR, Kroening R, Haley D, Siegert R. Myofascial pain syndrome of the head and neck: a review of clinical characteristics of 164 patients. Oral Surg Oral Med Oral Pathol 1985;60(6):615-23.

21. Nilner M, Ekberg E, Doepel M, Andersson J, Selovuo K, Le Bell Y. Short-term effectiveness of a prefabricated occlusal appliance in patients with myofascial pain. J Orofac Pain 2008;22(3):209-18.

22. Gerwin RD. Classification, epidemiology, and natural history of myofascial pain syndrome. Curr Pain Headache Rep 2001;5(5):412-20.

23. Alvarez DJ, Rockwell PG. Trigger points: diagnosis and management. Am Fam Physician 2002;65(4):653-60.

24. Madland G, Newton-John T, Feinmann C. Chronic idiopathic orofacial pain: I: What is the evidence base? $\mathrm{Br}$ Dent J 2001;191(1):22-4.

25. Sessle BJ. The neurobiology of facial and dental pain: present knowledge, future directions. J Dent Res 1987;66(5):962-81. 